\title{
Factors Affecting the Changes of Downstream Forestation in the South American River Channels
}

\author{
F. M. Jamil Uddin ${ }^{1,2}$, Takashi Asaeda ${ }^{1} \&$ Md H. Rashid ${ }^{1,2}$ \\ ${ }^{1}$ Department of Environmental Science \& Technology, Saitama University, Japan \\ ${ }^{2}$ Department of Agronomy, Bangladesh Agricultural University, Bangladesh \\ Correspondence: Takashi Asaeda, Department of Environmental Science \& Technology, Saitama University, 255 \\ Shimo-okubo, Sakura-ku, Saitama 338-8570, Japan. Tel: 81-48-858-3563. E-mail: asaeda@mail.saitama.u-ac.jp
}

Received: July 2, 2014 Accepted: August 4, 2014 Online Published: August 19, 2014

doi:10.5539/ep.v3n4p24 URL: http://dx.doi.org/10.5539/ep.v3n4p24

\begin{abstract}
Due to construction of dams on the river channels has caused enormous social and environmental impacts in South American countries which have been associated with vegetation dynamics in many studies. However, factors governing the spatial changes of forestation in the floodplain after dams have not been explored extensively. A total of 72 segments of 9 rivers (12 dams) located in five Southern American countries (Chile, Argentina, Uruguay, Paraguay and Brazil) were studied. This study examined the interacting effects of dam, inflow and land-use patterns of catchment areas and other factors on downstream vegetation patterns along the downstream reaches of some South American rivers. Forest and herbs vegetation coverage areas of river channels after a dam and land-use catchment area patterns were obtained by the Google area calculator and aerial image analysis. Forest coverage was the highest just below the dams, and the ratio of forest cover decreased with distance from the dam toward the river mouth. Forest coverage ratio was found to decrease with an increase in dyke distance, number of inflows $(\mathrm{r}=-0.814, p<0.01)$ and water coverage ratio, and bare land in the river flood plain. However, a principal component analysis (PCA) showed that the proportion of bare land in the catchment area, the dyke distance of the river and the number of inflows or tributaries are the factors most associated with forestation among the studied parameters. As a result of local deviation due to the entrance of tributaries after a dam, the effects produced by dams on vegetation as well as forestation are gradually decreased towards the downstream. Though in some cases different land use types such as agriculture areas reduce forest area, their impact on forestation was insignificant.
\end{abstract}

Keywords: channel flood plain, Inflows, forestation, bare land, flow regulation

\section{Introduction}

Riparian forests are important features of any ecosystem, especially on grassland and savannah vegetation types (Alonso Paz \& Bassagoda, 2002; Naiman et al., 2005). The world's largest continuous tropical forest and savannah ecosystem are situated in the tropical South America which generates about $25 \%$ of the global river discharge (Latrubesse, 2008). South America Climate differs from one region to another due to large size, South America can be divided into four major climatic regions - tropical, temperate, arid, and cold, determined by their geographical location, ocean currents and winds. The Amazon River basin has the typical hot wet climate suitable for the growth of rain forests. The desert region of Chile is the driest part of South America. The westerly winds carrying moisture shed their moisture on the western parts of the Andes, thus the eastern portions of the mountains receive very little rainfall. The highest temperatures of South America have been recorded in Gran Chaco in Argentina, with temperatures going up to 110 degrees F. The wettest place is Quibdo in Columbia. It receives an annual rainfall of 350 inches (890 centimeters). The climate of Uruguay is humid subtropical (according to the Koppen climate classification). It is fairly uniform nationwide, since the country is located entirely within the temperate zone. The climate of Paraguay consists of a subtropical climate in the Paranena region and a tropical climate in the Chaco. Climatic variability over the sub continental expanses reflect the variability of precipitation, evapotranspiration, lithology, topography and vegetation cover (Pasquini \& Depetris, 2007).

Due to regional development and global demand of agricultural commodities, tropical deforestation is driven even in amazon rainforest (Achard et al., 2002; Kaimowitz et al., 2004; Fearnside, 2005). Free-running rivers 
has changed in to short, fragmented free flowing reaches separated by impoundments due to construction of many hydro-electric dams in the South American rivers (Okada et al., 1996) which results the alteration of downstream forestation in the river channels (Tockner \& Stanford, 2002; Naiman et al., 2005; Nilsson et al., 2005). The alteration of a river's flow and sediment transport downstream of a dam often causes the greatest sustained environmental impacts. The spatial distribution of flood plain forest is strongly dependent on the flood system, particularly flooding, river bank erosion and sediment deposition, and the regeneration of riparian vegetation (Stanford et al., 2005).

The regeneration potential of floodplain forests gradually decreases due to increasing number of dams controlling river flows which reduces the flood peak and the frequency of overbank flow. Vegetation may increase or decrease in a regulated river depending on the climatic and geological characteristics of the region and channel incision after dam construction period (Steiger et al., 2005; Stromberg et al., 2007). Downstream river channels followed by dams become forested (Azami et al., 2004; Asaeda et al., 2009; Asaeda \& Rashid, 2012). Reduced disturbances in regulated rivers result in stable tree colonization in downstream reaches (Asaeda et al., 2010). Flow regime can promote or prevent the establishment of riparian trees (Friedman \& Auble, 1999) while in highly disturbed, steep and frequently flooded rivers are colonized by the pioneerin plant species which can tolerate the disturbances by their physiological and morphological atrributes (Capon, 2005; Asaeda et al., 2009). It is not clearly known about interacting effects of dam operation and land use systems on downstream vegetation dynamics while the potential effect of land use has been increasingly explored (Knox, 2001; Urban \& Rhoads, 2003). The increase of the amount of vegetation as well as forestation immediately downstream in the interval topical dam could potentially illustrate the changes in the amount of vegetation at longer distances from these dams.

There is not much available information on the longitudinal impacts of dams on vegetation, such as how far downstream and the degree of regulation to which a dam on a river can influence riparian woodlands (Bejarano et al., 2011). The effect of reduced annual flow fluctuations is due to not only regulation being the largest downstream from a dam, but also from the progressive decrease following the entrance of free-flowing tributaries, which causes local deviation (Bejarano et al., 2011). However, after the dam, there may be several tributaries, which add water flow in the main water flow channel and also play an important role of flood and sediment load. Dyke distances and steepness of rivers also affect riparian vegetation development. Although there are many studies that have dealt with the effect of dams on downstream environments, this effect depends on dam distance and location, effects of subsequent tributaries, and the number of inflows or tributaries, dyke distance.

In this paper, we examined how the forest changes in dams' downstream along with land coverage systems due to the interacting effects of dam and land use in South American Rivers. In our study, we aimed to test the following hypotheses:

1) Forest coverage changes due to the effects of dam operation in relation to the distance downstream from dams.

2) The inflows entering the main channel after the dam modify its effect on downstream vegetation.

3) The land use type of the river channel and catchment affect the changes downstream spatial pattern of forestation occur along the water course.

\section{Methods}

\subsection{General Methods}

Virtual globe software systems, such as Google Earth ${ }^{\circledR}$, are growing rapidly in popularity among scientists and environmental professionals as techniques to visualize and share 3D environmental data (Sheppard \& Cizek 2009). Recently, Google Earth ${ }^{\circledR}$ released high resolution images as free, open, and valid data sources or as visualization tools for land use/cover mapping (Mering et al. 2010; Kaimaris et al., 2011; Yu \& Gong, 2012). In this study, we used freely accessible Google $\operatorname{Earth}^{\circledR}$ (GE) satellite images in high spatial resolution as direct data resources to explore potential uses of land use/cover area (Duhl et al., 2012; Hu et al., 2013). Different land use areas were determined within the study area from an appropriate aerial (above ground) viewing height (or zoom) for making visual vegetation cover fractions using Google Earth ${ }^{\circledR}$ is 50-100 m (Duhl et al., 2012). Spatial land coverage data was obtained from April to December 2013 using available images from Google Earth $^{\circledR}$ (version 7.1.2.2041) (http://earth.google.com) (Barbosa \& Campos, 2011). We used the Google Earth ${ }^{\circledR}$ polygon creation tool to estimate land use as well as vegetation coverage area in the flood plain channel zone because it allows a more accurate interpretation of images by controlling distance and work scale alignment (Barbosa \& Campos, 
2011). Geographical spatial distribution of different land uses was detected by visual observation on Google Earth $^{\circledR}$ images without any digital processing (Barbosa \& Campos, 2011). Patches of forest, herbs, agricultural area, bare land, water area, wasteland and sandy or gravelly areas were visually identified from images as shown in (Figure 1c). Dams located in different regions in South American countries were selected for the study (Figure 1b). The administrative boundary shape files of different countries were processed in ArcView 9.3 (ESRI, 2008) to show the location of dams with their respective latitudes and longitudes. After the dams, in the downstream river channels along with flood plains, the following areas were measured using 2013 images in the Google area calculator. The parameters were classified as follows:

1) Flood Plain
a) Forest covered area
b) Grass or herbaceous covered area
c) Agricultural area
d) Wasteland area
e) Sandy or gravel area
f) Total area

2) Inside Channel
a) Forest covered area
b) Grass or herbaceous covered area
c) Sandy or gravel area
d) Total area

3) Sand Bars
a) Forest covered area
b) Grass or herbaceous covered area
c) Sandy or gravel area
d) Total area

4) Watered Area

The measurements for each studied river were conducted on both sides of the river bank with sand bars or island areas in the channels. The flood plain was considered the area between levies. Then, forest coverage ratio was calculated as the forest area divided by total area. Similarly, the ratios of herb coverage, agriculture area, sandy or gravelly area, wasteland area, and water coverage were calculated by dividing the abovementioned areas by the total area of the flood plain, respectively. The area covered by dead herbs, which was easily identified, was categorized as herb coverage. Areas near forests not vegetated, deforested, or not for cultural practices were documented as wasteland. The lands which cannot be categorize as the above mention classes and also found in the catchment area were stated as bare lands. The data was calculated by making segments from the dam to the first tributary, from first tributary to second tributary, from second tributary to third tributary, and so on. The tributaries entering the main river channel were considered by the number of inflows (Figure 1a). Downstream data was calculated for about $25 \mathrm{~km}$ following the dam, which varied in some cases based on the distance to the ocean. Dyke distance was measured in the river channel crosswise by the Google distance calculator in each segment, taking an average of more than 10 times/points. Data on maximum and minimum river stream flow rate $\left(\mathrm{m}^{3} / \mathrm{sec}\right)$ was collected from the Global River Discharge Database (SAGE, 2010). The analyzed river gauging stations were located downstream of the dams. Climatic data, such as annual mean temperature $\left({ }^{\circ} \mathrm{C}\right)$ and annual precipitation (mm), were obtained from global climate data (1950-2000) at 30 arc-seconds $(\sim 1 \mathrm{~km})$ resolution (Worldclim, 2005) and processed with the spatial analyst extension in ArcView 9.3 (ESRI, 2008). Data was collected for the following dams' downstream areas in different rivers across South America (Table 1).

\subsection{Statistical Analyses}

The data was analyzed using SPSS for Windows, Version 16 (SPSS. Inc., Chicago, IL, USA). Raw data of all of the variables was checked for normal distribution rates with the one-sample Kolmogorov-Smirnov test as well as for variance homogeneity with the Levene's test. When necessary, the arcsine transformation was also performed. A t-test and analysis of variance (ANOVA) followed by Tukey's posthoc tests were used throughout the data 
analysis to compare the means between the different sampling times. The Pearson's correlation test was used to determine the associations between variables. XLStat-Pro (version 2013.5.09), an add-in package of Microsoft Excel, was used to apply Principal component analysis (PCA) to the results.



(a) (b)

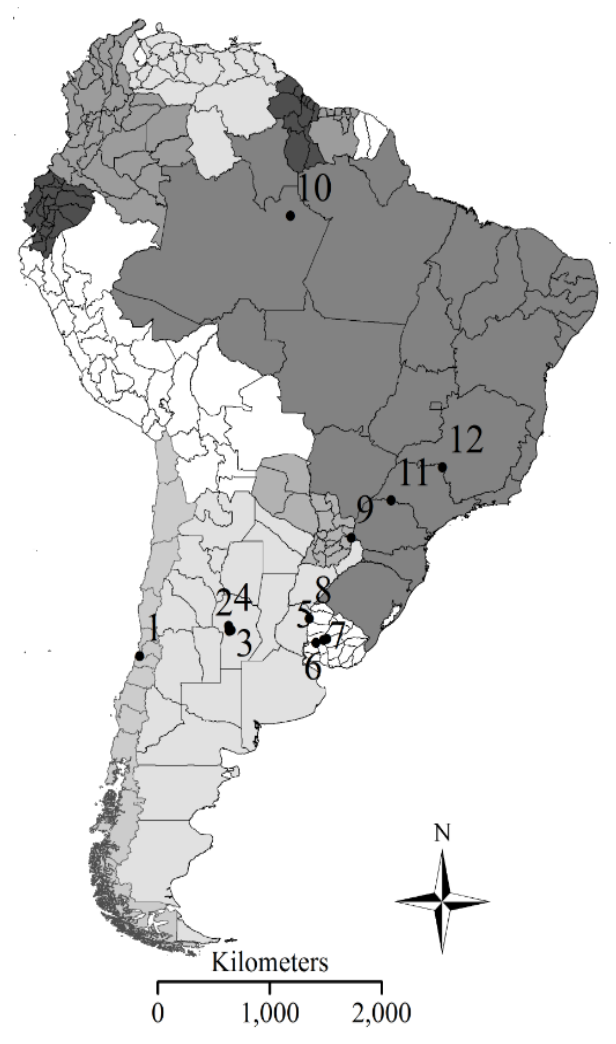

(c)

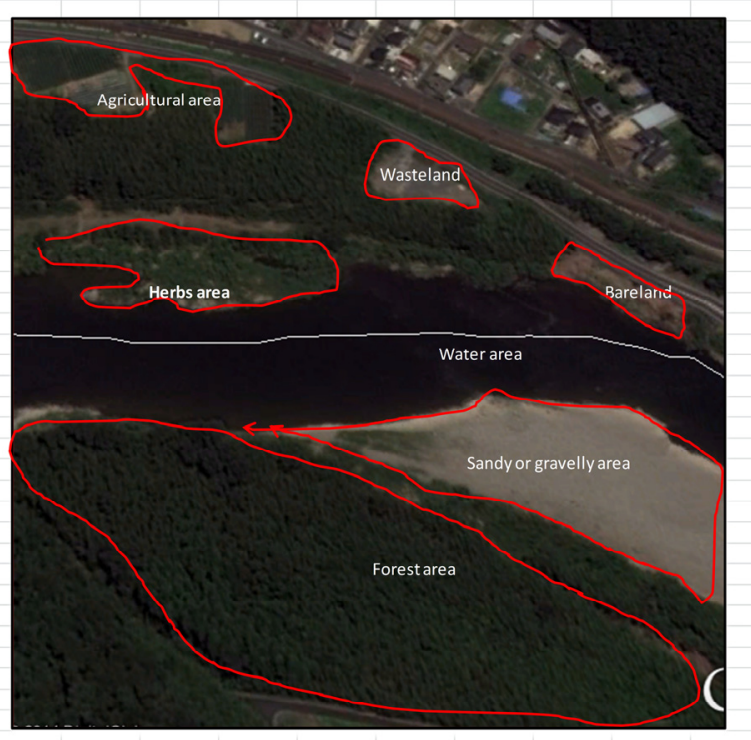

Figure 1. (a) A schematic presentation of dam and inflow segments of downstream reach of a river, (b) location of studied dams in North American countries (1=Rapel, 2=Embalse Piedras Moras 3=Lago Piedras Moras, 4=La Quintana, 5=Paso Del Palmar, 6=Rincon del Bonete, 7=Rincon de Baygorria, 8=Salto Grande, 9= Ittaipu, 10=Balbiana, 11=Capivara, 12=Peixoxtos), and (c) patches of forest, herbs, and sandy or gravelly area 
Table 1. List of dams surveyed in the study

\begin{tabular}{|c|c|c|c|c|c|c|c|c|c|}
\hline SI. & Name of dam & River & Country & Start of & Catchment & Capacity & \multicolumn{2}{|c|}{ Location } & Use \\
\hline 1 & Rapel & Rapel & Chile & 1968 & 80 & 530000 & Lat: -34.040 & Long: -71.588 & HP \\
\hline 2 & E. Ped. Moras & Tercero & Argentina & 1979 & 3.77 & - & Lat: -32.193 & Long: -64.404 & HP \\
\hline 3 & L. P. Moras & Tercero & Argentina & 1976 & 5.897 & - & Lat: -32.166 & Long: -64.246 & HP \\
\hline 4 & La Quintana & Segundo & Argentina & 1957 & - & - & Lat: -31.846 & Long: - 64.435 & HP \\
\hline 5 & P. Del Palmar & Negro & Uruguay & 1982 & 320 & 2854 & Lat: -33.075 & Long: -57.429 & HP \\
\hline 6 & R.D. Bonete & Negro & Uruguay & 1948 & 1070 & 8800 & Lat: -32.802 & Long: -56.569 & HP \\
\hline 7 & R.D. Baygorria & Negro & Uruguay & 1960 & 307 & - & Lat: -32.879 & Long: -56.823 & HP \\
\hline 8 & Salto Grande & Uruguay & Uruguay & 1979 & 224000 & 5000000 & Lat: -31.303 & Long: -57.974 & HP \\
\hline 9 & Ittaipu & Paraguay & Paraguay & 1984 & 1350000 & 29000000 & Lat: -25.412 & Long: -54.594 & HP \\
\hline 10 & Balbiana & Uatuma & Brazil & 1985 & 16502 & 17540000 & Lat: -1.9159 & Long: -59.485 & HP \\
\hline 11 & Capivara & Paranapanema & Brazil & 1978 & 80000 & 10540000 & Lat: -22.686 & Long: -51.383 & HP \\
\hline 12 & Peixostos & Grande Brazil & Brazil & 1968 & 250 & 2500000 & Lat: -20.284 & Long: 312.934 & HP \\
\hline
\end{tabular}

Cell with dash (-) mark has no data available. HP designate hydro-electric power dam, respectively.

\section{Results}

\subsection{Forestation Changes after Dam with Distance}

Just below the dams forest coverage ratio showed a high value and steadily decreased as distance increase from them, resulting in a strong correlation with distance $(\mathrm{r}=-0.732, p<0.01)$ (Figure 2$)$. The highest and the lowest forest coverage ratios were found in the downstream areas of the Paso Del palmar dam in Uruguay and the La Quintana dam in Argentina, respectively. In Uruguay and Argentina, the forest covered almost $52 \%$ and $42 \%$ with a maximum up to $58 \%$ and $48 \%$ of the total flood plain areas, respectively, just after the dams. Farther downstream (about $25 \mathrm{~km}$ from the dam), the forestation rates were around $32 \%$ and $21 \%$ of the total flood plain areas for Uruguay and Argentina, respectively. It was observed that a fraction of herb covered areas was larger showing an increasing trend from the dam in the downstream direction, whereas the forest covered a smaller proportion of the total flood plain area showing a decreasing trend for every studied dam in South America (Figure 3). A strong negative correlation was found between forest and herb coverage ratios $(\mathrm{r}=-0.655, \mathrm{p}<0.01)$ for all assessed Southern American dams. The forest coverage ratio had a decreasing trend, while the herb coverage ratio showed an increasing trend from the dam in the downstream direction for every studied dam in South America. 


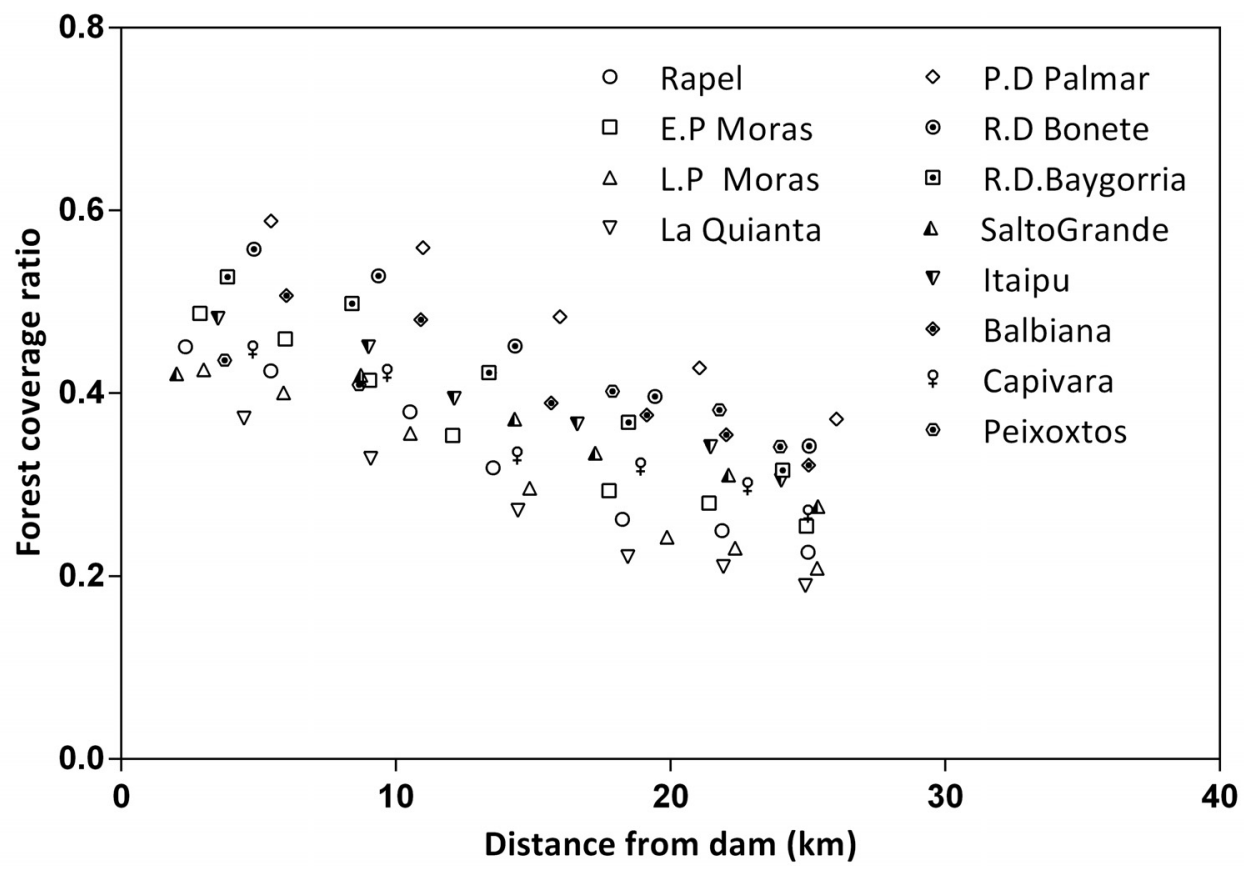

Figure 2. Relationship of the distance from dam towards river mouth and forest coverage ratio (FCR) downstream of the dams, respectively

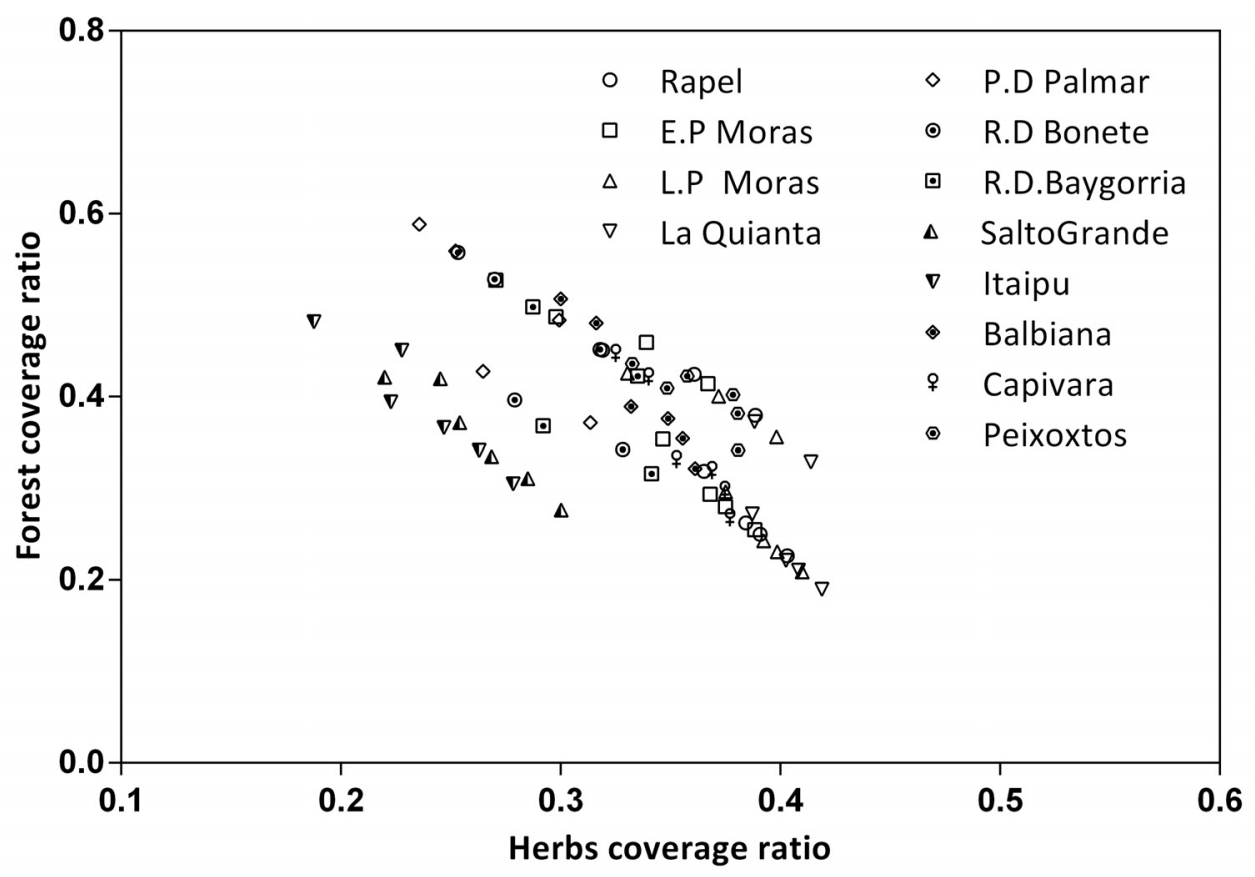

Figure 3. Relationship between herb coverage ratio and forest coverage ratio downstream of the dams, respectively

\subsection{Number of Inflows}

Figure 4 shows that, as the cumulative number of inflows toward the river mouth increases, the fraction of forest coverage decreased. A strong negative correlation was found between the number of inflows and the forest 
coverage ratio towards downstream $(\mathrm{r}=-0.814, p<0.01)$ for all evaluated South American dams. In the case of the Paso Del palmar dam, downstream forest coverage changed from $58 \%$ of the dam segments to $37 \%$ at distant segments after 5 inflows had entered the main stream; whereas in the La Quintana dam, 37\% forest coverage just below the dam eventually decreased to $18 \%$ at the distant segment after 6 inflows had joined the main channel. Forest coverage patterns were changed similarly in all other dams. Forest coverage ratio was very small when about 5-7 inflows entered the main channel compared to the forest ratio of dam segments, where only the main flow comes from the dam.

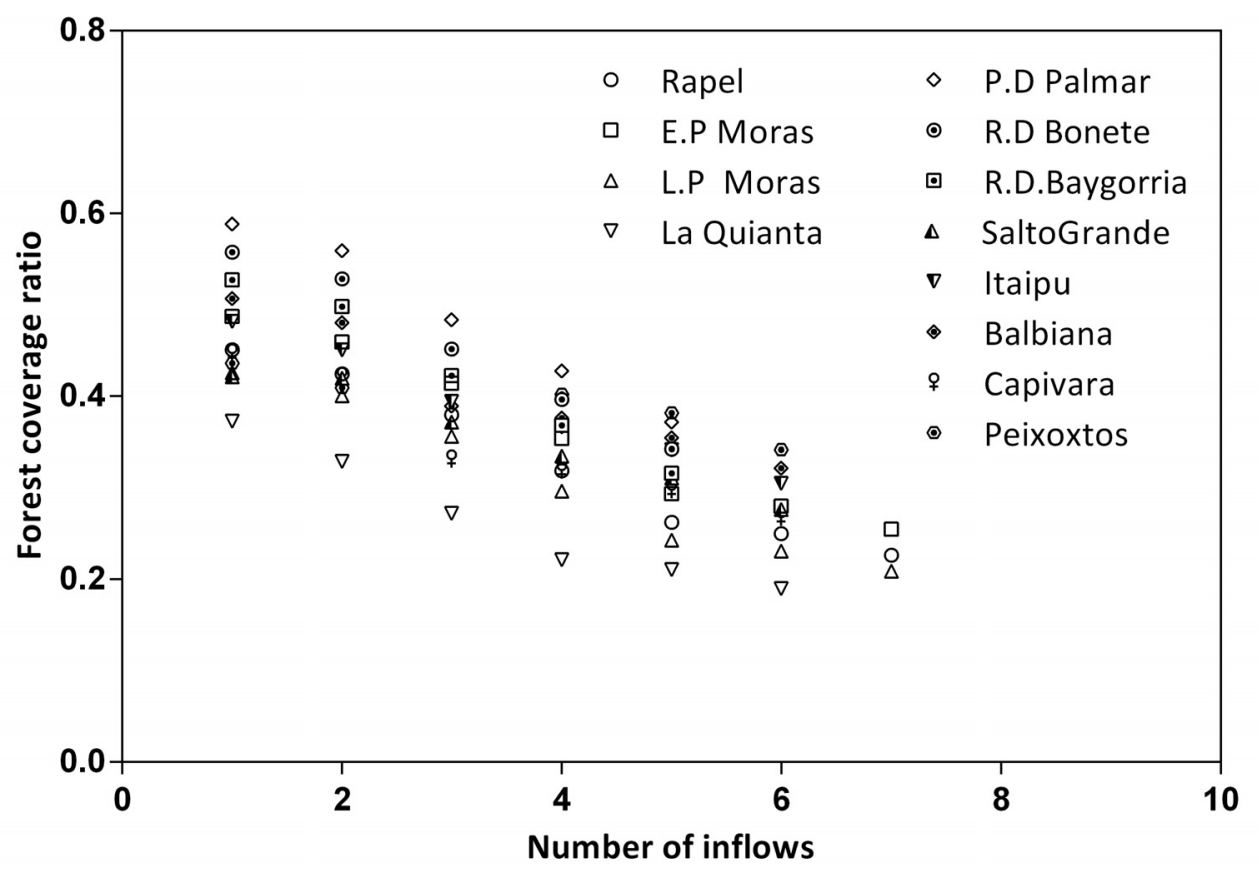

Figure 4. Relation between forest coverage ratio and number of inflows. Consecutive number of inflows was counted from dam towards downstream

\subsection{Distance between Dykes and Stream Flow}

A negative correlation was found between dyke distance and forest coverage ratio in the river channels below the dams: $(r=-0.608, p<0.05)$ for all studied dams (Figure 5). In the river channel, forest coverage ratio decreased with increasing dyke distance and the ratio is higher below the dams where the dyke distances are smaller compare to the distant downstream. The maximum distance between dykes after the dams in our study was 443 $\mathrm{m}$. Figure 6 shows the relationship between river stream flow rate ratio (max flow/min flow) and average forest coverage ratio in the river channels downstream from dams. A strong negative correlation was found between stream flow and the forest ratio $(r=-0.751, p<0.05)$. Forest coverage ratio decreased with increased stream flow in the river channels. 


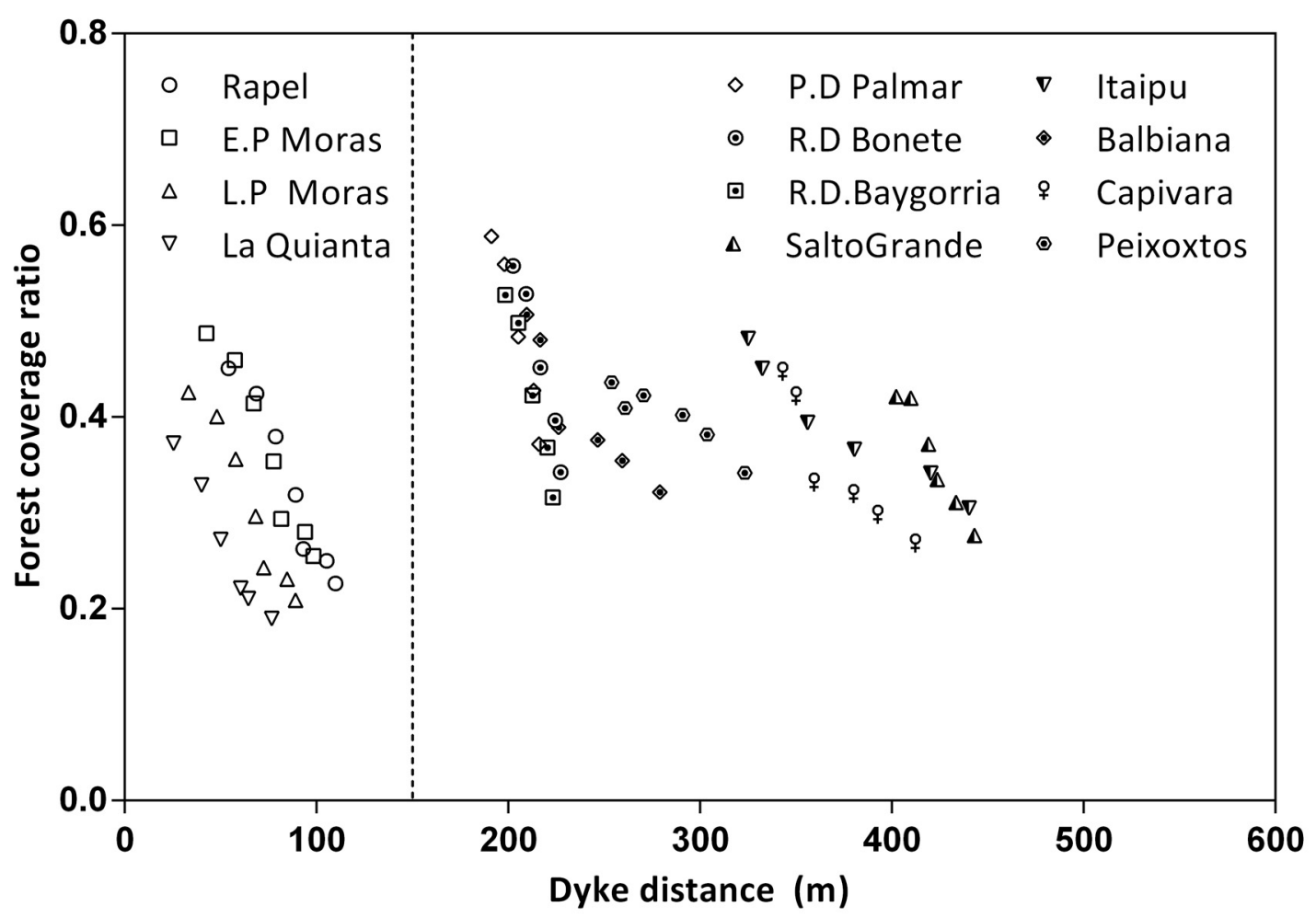

Figure 5. Showing relation between forest coverage ratio and dyke distance. Dams in the left panel of the graphs are located in Chile and Argentina, whereas the rest dams are located in Uruguay, Paraguay and Brazil

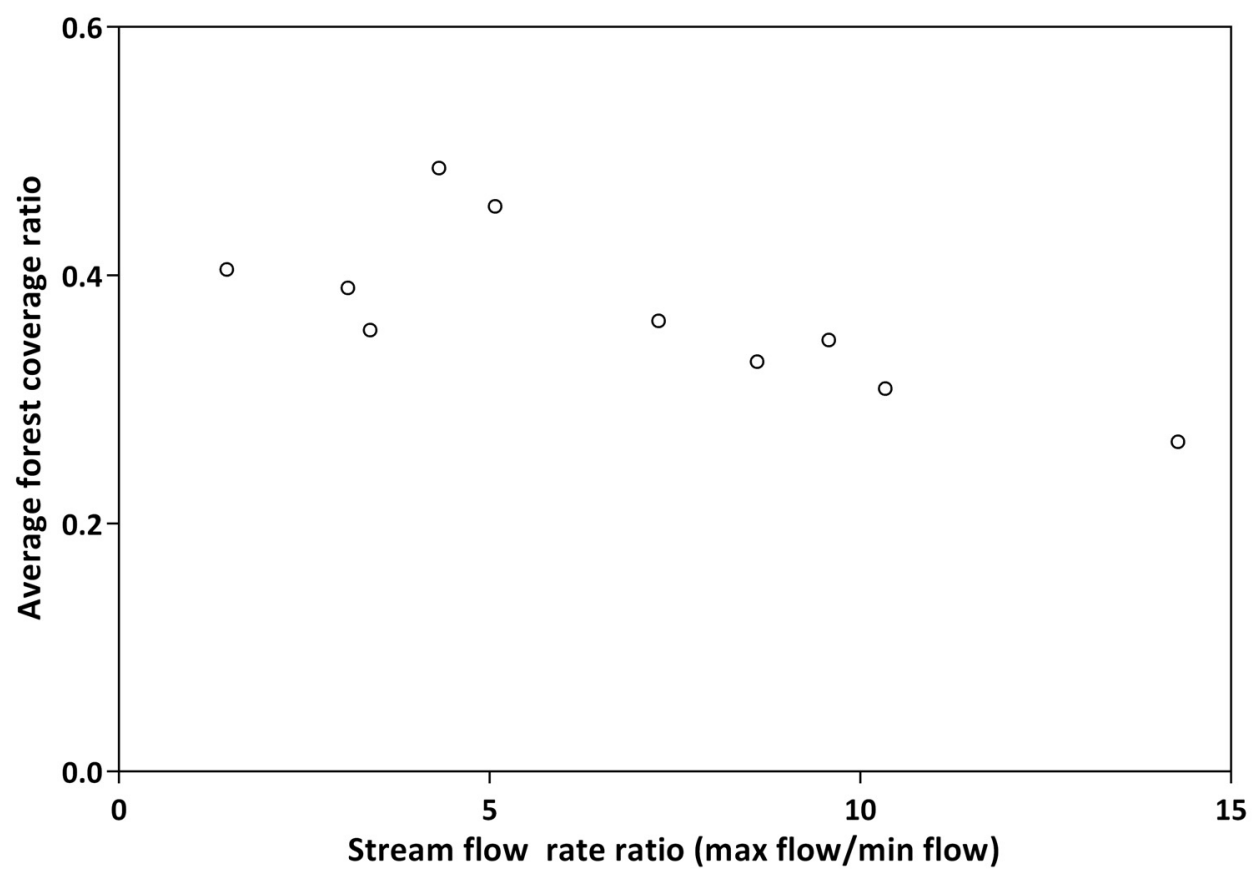

Figure 6. Relationship between river stream flow rate ratio ( $\max$ flow $/ \mathrm{min}$ flow) and average forest coverage ratio downstream of the dams 


\subsection{Forest Coverage Ratio and Land Use Pattern in the River Channel}

The forest coverage ratio was found to be negatively correlated with the water coverage ratio $(\mathrm{r}=-0.574, p<0.05)$ (data not shown) below the dams. The forest area ratio and the sandy or gravelly area ratio showed a negative correlation $(\mathrm{r}=-0.692, p<0.01)$ (data not shown). In Uruguay, sandy or gravelly area exposure was very small just below dams (about 13\%) due to the large forest coverage, and towards the downstream reaches, sandy or gravelly areas covered a larger portion of the river basin $(22 \%)$, which reduced forest areas in the flood plain. In Argentina, the highest forest coverage ratio values were found just below the dams where sandy or gravelly areas covered about $17 \%$ of the total flood plain area. However, towards downstream reaches, at about $25 \mathrm{~km}$, the forest ratio became smaller due to the larger sandy or gravelly area, which was more than $31 \%$ of the river basin. Similar trends were also found for all other countries.

The relation between forest coverage ratio and wasteland area ratio was negatively correlated but not statistically significant $(\mathrm{r}=-0.043, p=0.722)$ (data not shown). In Uruguay and Argentina, very little area was wasteland $(<$ $7 \%$ ) in the flood plain of the studied dams. It was observed that no agriculture area was used in the downstream river channels of the studied dams. However, in the case of some dams, e.g. Salto Grande, Uruguay and Itaipu, Paraguay, very little $(2.54 \%$ of the flood plain) land was used for agricultural purposes. However, towards downstream, where agricultural area increased, revealed a reduction in forest coverage in the flood plain.

\subsection{Effects of Catchment Land Use on River Channel Forestation}

The land use pattern of the catchment areas of the studied rivers strongly influenced river channel forestation after the dams (Figure 7). There was a distinct difference of land use system among the catchments of the studied dams. In Uruguay, the highest average forest coverage (48\%) was found in downstream reaches of the Paso Del palmar dam, and the land use in its catchment was $7.54 \%$ urban, $2.84 \%$ agricultural, $19.30 \%$ bare land (including $6.54 \%$ wasteland and $13.75 \%$ sandy or gravelly land). The lowest average forest coverage $(26 \%)$ was found in the La Quintana dam (in Argentina) flood plain, where the catchment land uses were $3.0 \%$ urban, 33\% agricultural, and $25.6 \%$ bare land (including $7.72 \%$ wasteland and $17.87 \%$ sandy or gravelly land). Similar results of variation in the land use pattern of the catchment were also found for all the other studied dams. For example, the average medium forest coverage (38\%) was found in the downstream reaches of Itaipu dam, Paraguay and the other land uses in its catchment were $8.48 \%$ urban, $9.86 \%$ agricultural, and $24.22 \%$ bare land (including $12.02 \%$ wasteland and $12.20 \%$ sandy or gravelly land). 

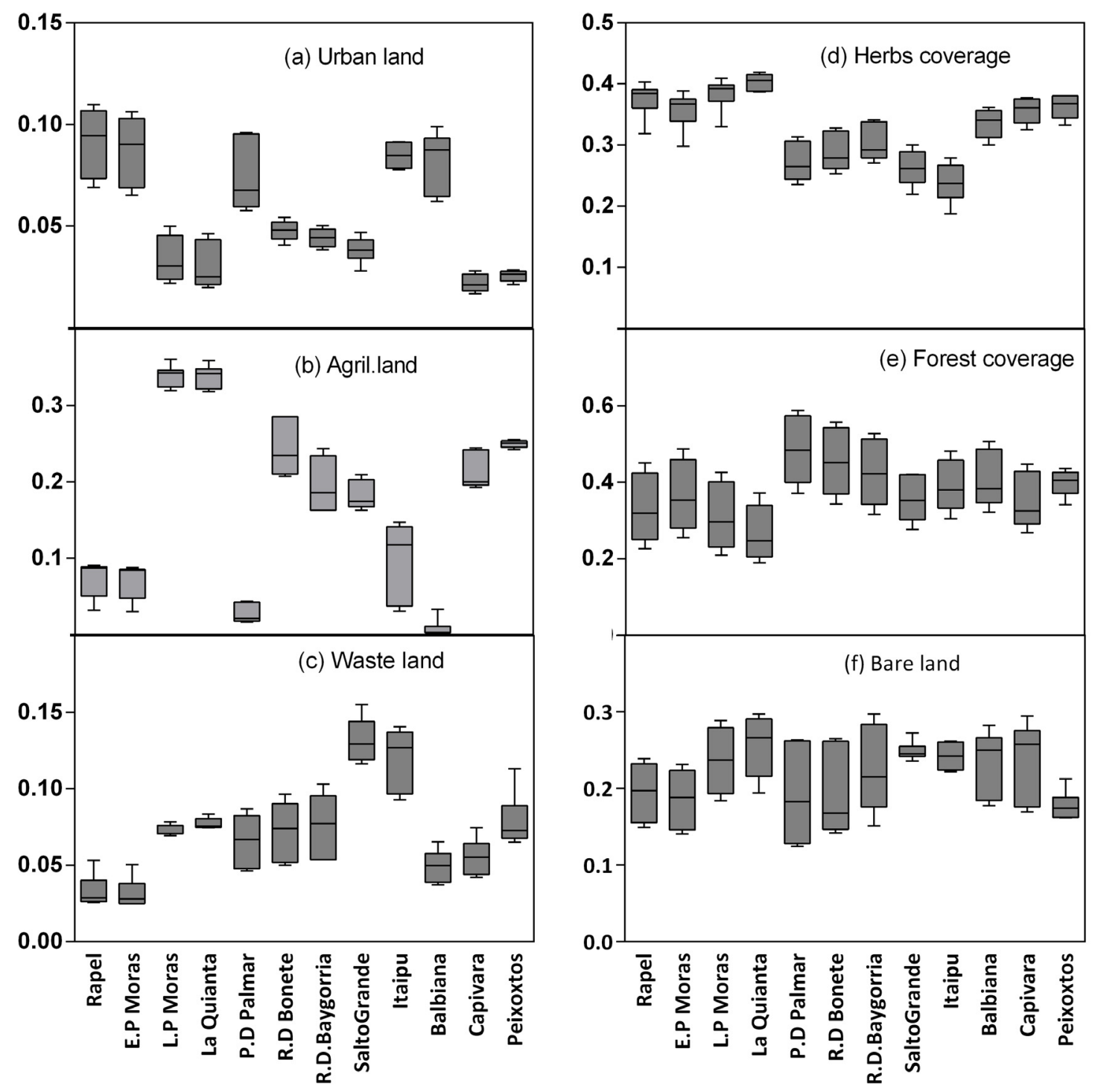

Figure 7. Fractions of (a) urban, (b) agricultural, (c) wasteland, (d) herbs coverage, (e) forest coverage of the river channel, and (f) bare land of the catchment area

\subsection{Effect of Climate on River Channel Forestation}

Figure 8 shows the relationship between climatic parameters (a) annual mean temperature and (b) annual precipitation with average forest coverage ratio of the downstream areas of dams. Any significant correlation was not found between annual mean temperature and forest ratio $(\mathrm{r}=0.220, p=0.492)$. On the other hand, forest coverage ratio showed an increasing trend with the increase of precipitation, but the relation was not significant $(\mathrm{r}=0.453, p=0.162)$. 


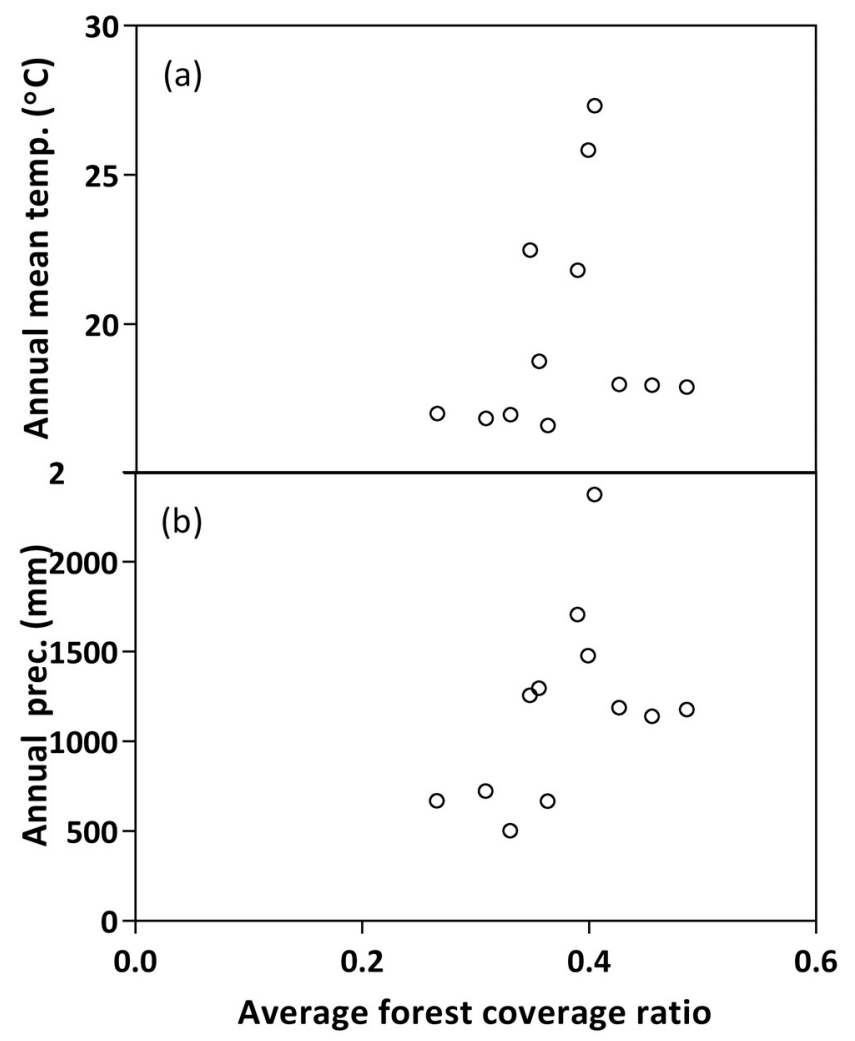

Figure 8. Relation of (a) annual mean temperature and (b) annual precipitation with average forest coverage ratio (FCR) downstream of the dams

\section{Discussion}

\subsection{Forestation Patterns along Downstream Reaches}

Figure 2 shows that the forest coverage area was larger in the immediate downstream areas from dams than in areas far downstream of the dams. Dam construction reduces the frequent flood disturbances which lead to increase riparian forests along the channels' incised banks (Franklin et al., 2001; Magilligan et al., 2003; Marston et al., 2005; Gordon \& Meentemeyer, 2006). Moreover, land use activities directly adjacent to the channel together influenced changes in riparian vegetation (Gordon \& Meentemeyer, 2006). Dam construction stabilizes downstream flows with little fluctuations, which have resulted in a large expansion of riparian forest towards channels. We observed that the herb coverage ratio showed an increasing trend in the downstream direction from the dams and the opposite relation was found with forest coverage ratio (Figure 3).

Herbs covered lower areas and forest covered a larger area immediately after the dams, while at a farther distance, herbs covered a larger area and forest covered a smaller area in the channels. As the total area of river channel flood plains remained the same, forest occupied a larger portion of the dam segments, which resulted in smaller areas for herb development. Herbs cannot grow well due to the shading effect below or near forest and also competition for sunlight, nutrients, and space (Schwinning \& Weiner, 1998). We also identified successive forest coverage area decrease towards downstream areas following the confluence with more free flowing water from entering tributaries (Figure 4). The number of tributaries increases towards downstream areas from the dams, which bring more flow, reducing forest coverage area in the flood plain. Tributaries supply sediments to the channel, which otherwise suffers from lack of sediment in the downstream of the dam.

Accumulation of sediment is an important disturbance to the channel vegetation (Asaeda \& Rajapakse, 2008). On the other hand, considering sediment produced through the channel sources which are principally derived from the bed, the banks of the streams and midpoint bar and the channel tributaries are deposited in the downstream channel and impeded vegetation growth (Wood \& Armitage, 1997). We observed that forest 
coverage area just after the dams is higher where dyke distance is smaller (Figure 5). Dyke distance increased towards downstream, and forest coverage area appeared smaller compared to that of dam segment areas. Dams narrow the water flow downstream and then forest becomes established on the bed (Friedman et al., 1998). The established forest stabilizes the channel at a narrower width by depositing fine sediments and increasing resistance to erosion (Smith, 1976). We observed that when water coverage area in the channel becomes larger in regards to total floodplain area, areas for vegetation development become smaller. Just below the dams before entering the first tributary, the water coverage area becomes smaller due to flow regulation by dams and sizable forest development. In contrast, from the first tributary to downstream areas, more tributaries enter the main channel, augmenting water flow and covering a wide area in the channel. As a result, the forest development area gradually decreases with an increase of water area in the channel.

We found that, sandy or gravelly areas that were not yet forested covered large areas of the flood plain, and forest areas covered a smaller portion (data not shown); this sandy or gravelly area may potentially become forested. The huge flux of sediment released from dams resulted in deposition in downstream channel and bars and was followed by intensive colonization of plants (Asaeda \& Rashid, 2012). The released sediment from the dam upstream shifted the nutrient stoichiometry of the riparian zone to a new equilibrium (Asaeda et al., 2011c), and this accumulated sediment on the riverbed, where one or more plant species might out-colonize the others or a new plant may invade a habitat with favorable soil nutrient conditions (Asaeda et al., 2011c). Deposited sediment in the river channel side banks facilitated flourishing plants living on the bottom of the rivers or streams (Asaeda \& Rashid, 2010; Asaeda et al., 2011a). The accumulation of sediment on the riparian zone creates favorable conditions for emerged saplings to grow into mature trees (Asaeda et al., 2011b).

Moreover, we observed a higher average forest coverage ratio with a lower ratio of maximum and minimum river flow rate, whereas there was a lower average forest coverage ratio in the case of higher flow ratio downstream (Figure 6). Due to dam construction, discharge was greatly reduced and regulated at a relatively constant flow downstream. This subsequent flow regulation led to forest development below the dams even close to water channels.

\subsection{Land Use Pattern and Forestation}

Increasing intensity of agriculture by land clearances leads to reduced forest area (Koskela et al., 2004). Land clearances and poor agricultural practices on the marginal lands of the river floodplain reduce the area of forest development. But in some cases, area may be covered as forest and for agriculture purposes, which may increase their ratio; while wasteland and sandy or gravelly areas may not cover that portion. Therefore, the relation between forest and agriculture area coverage ratios does not show any significant trend.

Within the flood plain, it was found that if the waste area is higher than other types, land use may be reduced. From this point of view, we observed that forest area was larger where waste area was smaller and vice versa. But in a few cases, it was observed that forest area and waste area were greater due to the reduction of other land use systems. Hence the relation between forest coverage ratio and wasteland coverage ratio was significant.

River channel and vegetation dynamics are also influenced by the surrounding landscape as well as by the supply of upslope of water, sediment, and wood (Montgomery \& MacDonald, 2002). Clearing upland forest can destabilize channel banks and riparian vegetation. Moreover, urban areas also occupied major areas of forest development alongside the river flood plain. These land cover changes have important impacts on the hydrology and sediment production in the downstream river flood plain (Vanacker et al., 2005). The catchment bare soil, which is susceptible to erosion and urban areas markedly increased sediments transported to the river channel via gullies, rills, landslides, soil creep, and surface runoff by rainfall, inhibits forest development (Wood \& Armitage, 1997). In our research, the largest forest area was observed in the Paso Del palmar dam (Uruguay), and other land use, such as agriculture, wasteland or bare land, sandy or gravelly land, and urban area, was less prevalent in the catchment areas that covered the dam's downstream reaches (Figure 7). On the other hand, the smallest forest coverage was found in downstream of the La Quintana dam (Argentina) due to higher proportions of bare land, sandy or gravelly land, urban area, wasteland, and agricultural land in the catchments. A similar relationship between downstream forestation and catchment land uses was also observed in cases of other dams.

\subsection{Effects of Dam Age and Locality}

Forest coverage ratio was observed lower in Argentina, and Chile, where the temperature was higher than other in countries, such as Brazil, Uruguay, and Paraguay, which had larger forest coverage area with lower temperature and higher precipitation (Figure 8). Seasonal water deficits results forest dieback due to lower precipitation and higher temperatures (Malhi et al., 2008). The spatial pattern of tree growth also declined with lower soil moisture, exerting increased stress due to the influence of higher temperature (Briffa et al., 1998). On 
the other hand, increased dam age meant larger forest area, but this relation has no significant effect on the forest coverage ratio in downstream channels $(\mathrm{r}=0.036, p=0.756)$ (data not shown).

\subsection{Multivariate Analyses}

Figure 9 is the ordination diagram for the principal component analysis (PCA) indicates a relationship between factors affecting downstream forestation. The analysis showed that the input variables correspond to $62 \%$ of total variability. It also appeared that forest coverage ratio (FCR), Total vegetation coverage ratio (TotVeg) and proportion of bare land in the catchment area (Catch-br), and number of inflows (Infl) are correlated to axis 1 (Figure 9, Table 2). On the other hand, dyke distance (Dyk_dis) average annual temperature (Temp), annual precipitation (Prec) and dam age (Dam age) were correlated to axis 2, which implies that they have no effect on FCR and TotVeg (Figure 9, Table 2). Though Urban (Catch_urb) and agriculture (Catch_agr) area in the catchment appears to be correlated with axis 1 , from Table 2 , it is clear that they are correlated to axis 3 , which indicates that it has no effect on FCR and TotVeg. The collateral trends of FCR and TotVeg, which coincides with our results. From PCA, It was observed that the proportion of bare land in the catchment area and the number of inflows are the most influential factors of changing FCR.

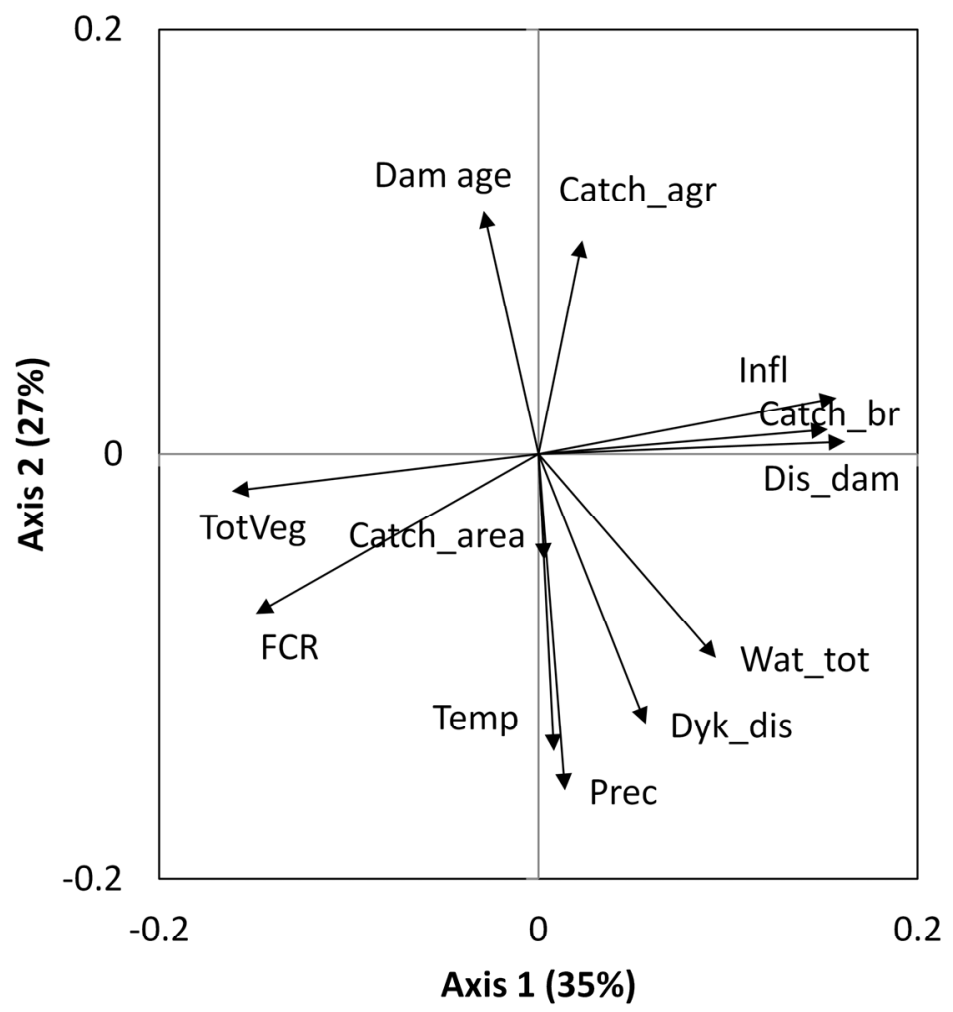

Figure 9. Principal component analysis (PCA) bi-plot for the first and second significant axes

The length of arrows along each axis increases with the strength of correlation with the respective axis scores. The angle between arrows indicates the degree of correlation with other variables. Variables are Dis_dam (distance from dam), Dam age ( age of dam from starting operation), Dyk_dis (dyke distance), Wat_tot (water coverage ratio in the flood plain), Catch_agr (catchment agricultural area ratio), Catch_Urb (catchment urban area ratio), Infl (number of inflows or tributaries), Catch_br (catchment bare land area ratio) average annual temeprature (Temp), annual preciputation (Prec), FCR (Forest coverage ratio), and TotVeg (Total vegetation coverage ratio). 
Table 2. Summary statistics of principal component analysis (PCA)

\begin{tabular}{lccc}
\hline Squared cosines of the variables & F1 & F2 & F3 \\
\hline Dam age & 0.026 & $\mathbf{0 . 4 0 6}$ & 0.132 \\
Dis_dam & $\mathbf{0 . 8 0 2}$ & 0.001 & 0.008 \\
Dyk_dis & 0.099 & $\mathbf{0 . 5 1 2}$ & 0.187 \\
Infl & $\mathbf{0 . 7 8 6}$ & 0.021 & 0.043 \\
Wat_tot & 0.270 & $\mathbf{0 . 2 8 9}$ & 0.038 \\
Catch_urb & 0.000 & 0.066 & $\mathbf{0 . 8 1 1}$ \\
Catch_agr & 0.017 & 0.320 & $\mathbf{0 . 5 6 3}$ \\
Catch_br & $\mathbf{0 . 7 1 2}$ & 0.004 & 0.003 \\
Temp & 0.003 & $\mathbf{0 . 6 3 4}$ & 0.084 \\
Prec & 0.006 & $\mathbf{0 . 7 9 6}$ & 0.042 \\
FCR & $\mathbf{0 . 7 0 2}$ & 0.175 & 0.004 \\
TotVeg & $\mathbf{0 . 8 1 6}$ & 0.010 & 0.001 \\
\hline Eigenvalues & F1 & F2 & F3 \\
\hline Eigenvalue & 4.884 & 3.872 & 2.381 \\
\hline Variability (\%) & 32.561 & 25.815 & 15.872 \\
\hline Cumulative (\%) & 32.561 & 58.375 & 74.248 \\
\hline
\end{tabular}

Values in bold correspond for each variable to the factor for which the squared cosine is the largest.

\section{Conclusion}

From the results of this study, we observed that forest coverage ratio is the largest just below dams due to flow regulation and reduces gradually towards downstream. The decreasing trend of forest coverage from dams to downstream areas with distance suggests that other factors are also responsible for changing this pattern. In this study we found that the physical factors, e.g., dyke distance, water coverage ratio, number of inflows, and land use types, such as agriculture, wasteland, sandy or gravelly, and bare land areas, etc., were also important in addition to flow regulation by dams governing spatial patterns of forestation in downstream river floodplains. Below dams, forest coverage ratio was found the largest where dyke distance, water coverage in the channel and the number of tributaries were smaller. Forest coverage gradually decreases towards downstream direction with distance due to increase of dyke distance, bank full area of water in the river channel and number entering tributaries in to the main channel. On the other hand, climatic parameters (annual mean temperature and annual precipitation) and land use of catchment affect the forest coverage ratio of the downstream reaches. Land use types, such as agriculture, wasteland, sandy or gravelly area, and bare land areas, etc., either in the river channel or catchment area reduces the downstream forest coverage though in some cases their impact on forestation was insignificant. Among the studied physical factors and land use systems, proportion of catchment bare land and the number of inflows/tributaries were identified as the most governing factors for the changes downstream spatial pattern of forestation occur along the water course.

\section{Acknowledgements}

This research was financially supported by a grant-in-aid from the Ministry of Education, Culture, Sports, Science and Technology (MEXT) and the Ministry of Land, Infrastructure, Transportation and Tourism in Japan.

\section{References}

Achard, F., Eva, H. D., Stibig, H.-J., Mayaux, P., Gallego, J., Richards, T., \& Malingreau, J.-P. (2002). Determination of deforestation rates of the world's humid tropical forests. Science, 297, 999-1002. http://dx.doi.org/10.1126/science.1070656

Alonso Paz, E., \& Bassagoda, M. J. (2002). La vegetación costera del SE uruguayo: ambientes y biodiversidad. Rev Mus Hist Nat Antropol, 5, 1-16.

Asaeda, T., Baniya, M. B., Rashid, M. H. (2011). Effect of floods on the growth of Phragmites japonica on the 
sediment bar of regulated rivers: a modelling approach. Int. J. Riv. Basin Mangag, 9, 211-220. http://dx.doi.org/10.1080/15715124.2011.613837

Asaeda, T., Gomes, P. I. A., Sakamoto, K., \& Rashid, M. H. (2011). Tree colonization trends on a sediment bar after a major flood. River Res. Appl., 27, 976-984. http://dx.doi.org/10.1002/rra.1372

Asaeda, T., Gomes, P. I. A., \& Takeda, E. (2010). Spatial and temporal tree colonization in a midstream sediment bar and the mechanisms governing tree mortality during a flood event. River Res. Appl., 26, 960-976.

Asaeda, T., \& Rajapakse, L. (2008). Effects of spates of different magnitudes on a Phragmites japonica population on a sandbar of a frequently disturbed river. River Res. Appl., 24, 1310-1324. http://dx.doi.org/10.1002/rra.1128

Asaeda, T., \& Rashid, M. H. (2010). Effects of hydrological changes on algal blooming in the reservoir and the required modification for treatments. Proc. 8th Int. Sympos. Hydrol., 91-97.

Asaeda, T., \& Rashid, M. H. (2012). The impacts of sediment released from dams on downstream sediment bar vegetation. J. Hydrol., 430-431: 25-38. http://dx.doi.org/10.1016/j.jhydrol.2012.01.040

Asaeda, T., Rashid, M. H., Kotagiri, S., \& Uchida, T. (2011). The role of soil characteristics in the succession of two herbaceous lianas in a modified river floodplain. River Res. Appl., 27, 591-601. http://dx.doi.org/10.1002/rra.1374

Asaeda, T., Siong, K., Kawashima, T., \& Sakamoto, K. (2009). Growth of Phragmites japonica on a sandbar of regulated river: morphological adaptation of the plant to low water and nutrient availability in the substrate. River Res. Appl., 25, 874-891. http://dx.doi.org/10.1002/rra.1191

Azami, K., Suzuki, H., \& Toki, S. (2004). Changes in riparian vegetation communities below a large dam in a monsoonal region: Futase Dam, Japan. River Res. Appl., 20, 549-563. http://dx.doi.org/10.1002/rra.763

Barbosa, R. I., \& Campos, C. (2011). Detection and geographical distribution of clearing areas in the savannas ('lavrado) of Roraima using Google Earth web tool. J. Geogr. Reg. Plann., 4, 122-136.

Bejarano, M. D., Nilsson, C., Tanago, M. G. D., \& Marchamalo, M. (2011). Responses of riparian trees and shrubs to flow regulation along a boreal stream in northern Sweden. Freshw. Biol., 56, 853-866. http://dx.doi.org/10.1111/j.1365-2427.2010.02531.x

Briffa, K., Schweingruber, F., Jones, P., Osborn, T., Shiyatov, S., \& Vaganov, E. (1998). Reduced sensitivity of recent tree-growth to temperature at high northern latitudes. Nature, 391, 678-682. http://dx.doi.org/10.1038/35596

Capon, S. J. (2005). Flood variability and spatial variation in plant community composition and structure on a large arid floodplain. J. Arid Environ., 60, 283-302. http://dx.doi.org/10.1016/j.jaridenv.2004.04.004

Duhl, T. R., Guenther, A., \& Helmig, D. (2012). Estimating urban vegetation cover fraction using Google Earth ${ }^{\circledR}$ images. J. Land Use Sci., 7, 311-329. http://dx.doi.org/10.1080/1747423X.2011.587207

Fearnside, P. M. (2005). Deforestation in Brazilian Amazonia: history, rates, and consequences. Conserv. Biol., 19, 680-688. http://dx.doi.org/10.1111/j.1523-1739.2005.00697.x

Franklin, S. B., Pezeshki, R. S., Scheff, T. L., Kupfer, J. A., Hanson, R. A., \& Gentry, R. W. (2001). A comparison of hydrology and vegetation between a channelized stream and a nonchannelized stream in western Tennesse. Phys. Geogr., 22, 254-274.

Friedman, J. M., \& Auble, G. T. (1999). Mortality of riparian box elder from sediment mobilization and extended inundation. Regul. Rivers: Res. $\quad$ Mgmt., $15, \quad$ 463-476. http://dx.doi.org/10.1002/(SICI)1099-1646(199909/10)15:5<463::AID-RRR559>3.0.CO;2-Z

Friedman, J. M., Osterkamp, W. R., Scott, M. L., \& Auble, G. T. (1998). Downstream effects of dams on channel geometry and bottomland vegetation: Regional patterns in the great plains. Wetlands, 18, 619-633. http://dx.doi.org/10.1007/BF03161677

Gordon, E., \& Meentemeyer, R. K. (2006). Effects of dam operation and land use on stream channel morphology and riparian vegetation. Geomorphol, 82, 412-429. http://dx.doi.org/10.1016/j.geomorph.2006.06.001

Hu, Q., Wu, W., Xia, T., Yu, Q., Yang, P., Li, Z., \& Song, Q. (2013). Exploring the Use of Google Earth Imagery and Object-Based Methods in Land Use/Cover Mapping. Remote Sens., 5, 6026-6042. http://dx.doi.org/10.3390/rs5116026

Kaimaris, D., Georgoula, O., Patias, P., \& Stylianidis, E. (2011). Comparative analysis on the archaeological 
content of imagery from Google Earth. J. Cult. Herit., 12, 263-269. http://dx.doi.org/10.1016/j.culher.2010.12.007

Kaimowitz, D., Mertens, B., Wunder, S., \& Pacheco, P. (2004). Hamburger connection fuels Amazon destruction. Bangor, Indonesia: Center for International Forest Research.

Knox, J. C. (2001). Agricultural influence on landscape sensitivity in the Upper Mississippi River Valley. CATENA, 42, 193-224. http://dx.doi.org/10.1016/S0341-8162(00)00138-7

Koskela, E., Amacher, G. S., \& Ollikainen, M. (2004). Deforestation, Production Intensity and Land Use under Insecure Property Rights. Retrieved January 28, 2014, from http://papers.ssrn.com/sol3/papers.cfm?abstract_id=516262

Latrubesse, E. M. (2008). Patterns of anabranching channels: The ultimate end-member adjustment of mega rivers. Geomorphol, 101, 130-145. http://dx.doi.org/10.1016/j.geomorph.2008.05.035

Magilligan, F. J., Nislow, K. H., \& Graber, B. E. (2003). Scale-independent assessment of discharge reduction and riparian disconnectivity following flow regulation by dams. Geology, 31, 569-572. http://dx.doi.org/10.1130/0091-7613(2003)031<0569:SAODRA>2.0.CO;2

Malhi, Y., Roberts, J. T., Betts, R. A., Killeen, T. J., Li, W., \& Nobre, C. A. (2008). Climate change, deforestation, and the fate of the Amazon. Science, 319, 169-172. http://dx.doi.org/10.1126/science.1146961

Marston, R. A., Mills, J. D., Wrazien, D. R., Bassett, B., \& Splinter, D. K. (2005). Effects of Jackson Lake Dam on the Snake River and its floodplain, Grand Teton National Park, Wyoming, USA. Geomorphol, 71, 79-98. http://dx.doi.org/10.1016/j.geomorph.2005.03.005

Mering, C., Baro, J., \& Upegui, E. (2010). Retrieving urban areas on Google Earth images: Application to towns of West Africa. Int. J. Remote Sens., 31, 5867-5877. http://dx.doi.org/10.1080/01431161.2010.512311

Montgomery, D. R., \& MacDonald, L. H. (2002). Diagnostic approach to stream channel assessment and monitoring. J Am. Water Resour. Assoc., 38, 1-16. http://dx.doi.org/10.1111/j.1752-1688.2002.tb01530.x

Naiman, R., Décamps, H., \& McClain, M. (2005). Riparia: Ecology, Conservation, and Management of Streamside Communities. Academic Press.

Nilsson, C., Reidy, C. A., Dynesius, M., \& Revenga, C. (2005). Fragmentation and flow regulation of the world's large river systems. Science, 308, 405-408. http://dx.doi.org/10.1126/science.1107887

Okada, E., Agostinho, A., \& Petrere, Jr M. (1996). Catch and effort data and the management of the commercial fisheries of Itaipu reservoir in the upper Paraná river, Brazil. Stock Assessment in Inland Fisheries. Fishing News Books, Oxford.

Pasquini, A. I., \& Depetris, P. J. (2007). Discharge trends and flow dynamics of South American rivers draining the southern Atlantic seaboard: An overview. J. Hydrol., 333, 385-399. http://dx.doi.org/10.1016/j.jhydrol.2006.09.005

SAGE. (2010). Center for Sustainability and the Global Environment, Gaylord Nelson Institute for Environmental Studies, University of Wisconsin-Madison. Retrieved February 10, 2014, from http://www.sage.wisc.edu/riverdata/scripts/world_map_med.php?qual=32\&newxy=?422,92

Schwinning, S., \& Weiner, J. (1998). Mechanisms determining the degree of size asymmetry in competition among plants. Oecologia, 113, 447-455. http://dx.doi.org/10.1007/s004420050397

Sheppard, S. R., \& Cizek, P. (2009). The ethics of Google Earth: Crossing thresholds from spatial data to $\begin{array}{lllll}\text { landscape } \quad \text { visualisation. } & \text { J. }\end{array}$ http://dx.doi.org/10.1016/j.jenvman.2007.09.012

Smith, D. G. (1976). Effect of vegetation on lateral migration of anastomosed channels of a glacier meltwater

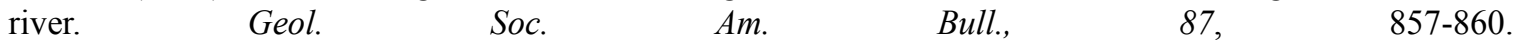
http://dx.doi.org/10.1130/0016-7606(1976)87<857:EOVOLM>2.0.CO;2

Stanford, J., Lorang, M., \& Hauer, F. (2005). The shifting habitat mosaic of river ecosystems. Proc. Int. Assoc. Theor. Appl. Limnol., 29, 123-136.

Steiger, J., Tabacchi, E., Dufour, S., Corenblit, D., \& Peiry, J. L. (2005). Hydrogeomorphic processes affecting riparian habitat within alluvial channel-floodplain river systems: A review for the temperate zone. River Res. Appl., 21, 719-737. http://dx.doi.org/10.1002/rra.879

Stromberg, J. C., Beauchamp, V. B., Dixon, M. D., Lite, S. J., \& Paradzick, C. (2007). Importance of low-flow 
and high-flow characteristics to restoration of riparian vegetation along rivers in arid south-western United States. Freshw. Biol., 52, 651-679. http://dx.doi.org/10.1111/j.1365-2427.2006.01713.x

Tockner, K., \& Stanford, J. A. (2002). Riverine flood plains: Present state and future trends. Environ. Conserv., 29, 308-330. http://dx.doi.org/10.1017/S037689290200022X

Urban, M. A., \& Rhoads, B. L. (2003). Catastrophic human-induced change in stream-channel planform and geometry in an agricultural watershed, Illinois, USA. Ann. Assoc. Am. Geogr., 93, 783-796. http://dx.doi.org/10.1111/j.1467-8306.2003.09304001.x

Vanacker, V., Molina, A., Govers, G., Poesen, J., Dercon, G., \& Deckers, S. (2005). River channel response to short-term human-induced change in landscape connectivity in Andean ecosystems. Geomorphol, 72, 340-353. http://dx.doi.org/10.1016/j.geomorph.2005.05.013

Wood, P. J., \& Armitage, P. D. (1997). Biological effects of fine sediment in the lotic environment. Environ. Manag., 21, 203-217. http://dx.doi.org/10.1007/s002679900019

Worldclim. (2005). WorldClim-Global Climate Data. Free climate data for ecological modeling and GIS. Retrieved March 10, 2014, from http://www.worldclim.org

Yu, L., \& Gong, P. (2012). Google Earth as a virtual globe tool for Earth science applications at the global scale: Progress and perspectives. Int. J. Remote Sens., 33, 3966-3986. http://dx.doi.org/10.1080/01431161.2011.636081

\section{Copyrights}

Copyright for this article is retained by the author(s), with first publication rights granted to the journal.

This is an open-access article distributed under the terms and conditions of the Creative Commons Attribution license (http://creativecommons.org/licenses/by/3.0/). 